\title{
Specific identification, biology and symptoms of whitefly species infesting sunflower in South India
}

\author{
V. N. Ghante, L. Rajesh Chowdary", M. R. Govindappa, M. Bheemanna and Arunkumar \\ Hosamani
}

Department of Agril. Entomology, Main Agricultural Research Station, University of Agricultural Sciences, Raichur (Karnataka), INDIA

*Corresponding author. E-mail: chowdaryrajesh@hotmail.com

Received: May 01, 2014. Revised received: August 24, 2014 Accepted: September 26, 2014

\begin{abstract}
Whitefly species related to sunflower was identified as Bemisia tabaci (Gennadius). Further the identified whitefly species was confirmed to be indigenous $B$. tabaci on molecular basis by using B-biotype specific SCARs and biological silver leaf assay on sensitive pumpkin (cv Big variety). None of the whitefly samples could positive for the presence of $B$ biotype. The results of the study on the pest life cycle under the laboratory conditions showed that, $B$. tabaci passed through four nymphal instars before the adult stage. The mean duration values of these stages were 5.6, 4.2, 4.4 and 5.6 days respectively. The total duration of the life cycle of $B$. tabaci ranged from 2342 days at the temperature of $29 \pm 2^{\circ} \mathrm{C}$ with a mean of 34.5 . The damage to sunflower crop caused by the whitefly species is discussed with a special emphasis on its ability to transmit leaf curl viral disease.
\end{abstract}

Keywords: Bemisia tabaci, Indigenous, Leaf curl viral disease, Sunflower, Vector, Whitefly

\section{INTRODUCTION}

Sunflower is an important short duration crop grown for its edible oils. It is a crop of choice for farmers due to its wider adaptability, high yield potential shorter duration and profitability (Lavanya et al., 2005). In the world it is cultivated in an area of 20 million ha with production of 3 million tons, whereas in India it is cultivated in 18.85 lac ha with production of 12.52 lac tons. Karnataka is one of the major sunflower growing states in India (Anonymous, 2009). Whitefly, Bemisia tabaci (Genn.) (Hemiptera: Aleyrodidae) is a major pest of many crops and important vector of geminiviral pathogens worldwide. B. tabaci has been considered as a species complex containing numerous genetic and biological variants undergoing continuous evolutionary changes (Brown, 2000; Perring, 2001). Of the many biotypes recognized, the B-biotype (silver leaf whitefly) due to its widest distribution, attributed to its ability to colonize many diverse plant hosts and remarkable ability to transmit a number of geminiviral diseases and has become a recognized pest of quarantine significance. Though morphologically indistinguishable, this biotype is biologically distinct from other biotypes of B. tabaci. It is more fecund, produces greater amount of honeydew, has a broader host range, exhibits significantly higher levels of insecticide resistance and induces severe phytotoxic disorders in certain plant hosts (De Barro et al., 2000).

Recently, whitefly has emerged as the new potential sucking insect pest of sunflower and also acting as the vector of leaf curl begomovirus in Northern Karnataka, India. This has attracted lot of attention of the Entomologists and pathologists, as it affects the productivity of sunflower an important oilseed crop in the country (Katti Pramod, 2007). Sunflower leaf curl disease vectored by whitefly was noticed for the first time in the country and the disease was recorded on sunflower hybrid 'Sun breed-275' up to 40 per cent disease incidence in the fields of Main Agricultural Research Station, University of Agricultural Sciences, Raichur, Northern Karnataka, during rabi season of 2009 (Govindappa et al., 2011). Since then, the whitefly infestation has been noticed in an endemic form consecutively for the last two years in sunflower growing areas of northern districts of Karnataka. The incidence is ranging from $10-58$ per cent by disease and correspondingly the increased population of $B$. tabaci (up to 200/leaf) was observed with an average of $14.7 \mathrm{~B}$. tabaci per leaf both in open pollinated varieties and hybrids. Sunflower is an important oil seed of the country. There have not been any published reports on whiteflies associated with sunflower in India. Therefore, the present study was conducted to identify, study the biology and symptoms of the whitefly species on sunflower.

\section{MATERIALS AND METHODS}

Collection and identification of whiteflies: Whitefly adults and pupal cases were collected from sunflower ISSN : 0974-9411 (Print), 2231-5209 (Online) All Rights Reserved @ Applied and Natural Science Foundation www.ansfoundation.org 
plants in Raichur. Adults were collected using an aspirator and preserved in $70 \%$ alcohol for identification. Pupal cases were collected using fine point paint brush (No. 00) and preserved in $70 \%$ alcohol. The collected specimens of whiteflies were despatched to the Institute of Wood Science and Technology, Bangalore, Karnataka, for identification.

Identification of B-biotype or Non B-biotype of whitefly: The DNA extraction from individual whitefly followed a standard protocol (Gupta et al., 2006). Briefly, each individual whitefly was homogenized with a micropestle in a $1.5 \mathrm{ml}$ microcentrifuge tube containing $25 \mu \mathrm{l}$ lysis buffer $(10 \mathrm{mM} \mathrm{KCl}, 2 \mathrm{mM}$ Tris-Cl, pH 8.4, $60 \mu \mathrm{g} \mathrm{ml}^{-1}$ proteinase $\mathrm{K}, 0.09 \%$ each of Nonidet NP-40 and Tween-20). The homogenate was treated at $65^{\circ} \mathrm{C}$ for $45 \mathrm{~min}$ and then, at $95^{\circ} \mathrm{C}$ for 5 min. The extract was diluted two-fold with sterile water and spun for $2 \mathrm{~min}$ at 10,000 RPM to pallet the debris. The supernatant containing the extracted DNA (10-15 ng $\left.\mathrm{ul}^{-1}\right)$ was transferred to another microcentrifuge tube and stored at $20^{\circ} \mathrm{C}$ (Chu et al., 2005; Boykin et al., 2007).

Comparative SCAR DNA-PCR amplifications were performed with four SCAR primer sets (BbA01970, BbF16269, BbF07573 and BB-1) that were earlier found to differentiate B-biotype from non B-biotype whitefly due to consistent amplification of specific polymorphic DNA fragments from B-biotype only (Shankarappa et al., 2007 and Gupta et al., 2008) (Table 2). PCR was performed in a $25 \mathrm{ml}$ reaction mix containing $6.0 \mathrm{mM}$ Tris- $\mathrm{HCl}, \mathrm{pH} 8.8$, and $1.5 \mathrm{mM}$ $\mathrm{MgCl}_{2}, 0.2 \mathrm{mM}$ dNTPs, $0.4 \mathrm{mM}$ forward and reverse primers, 2.5U of Taq DNA polymerase (Bangalore Genie Pvt Ltd, Bangalore) and $2 \mathrm{ml}$ whitefly DNA sample. PCR reactions were carried out with the following amplification program: 1 cycle of $2 \mathrm{~min}$ at $94^{\circ} \mathrm{C}$ followed by 35 cycles of $1 \mathrm{~min}$ at $94^{\circ} \mathrm{C}, 1 \mathrm{~min}$ at $58^{\circ} \mathrm{C}$ and $1 \mathrm{~min}$ at $72^{\circ} \mathrm{C}$, followed by a final cycle of $10 \mathrm{~min}$ at $72^{\circ} \mathrm{C}$ for BB-1 primer set and 1 cycle of 2 min at $94^{\circ} \mathrm{C}$ followed by 35 cycles of $1 \mathrm{~min}$ at $94^{\circ} \mathrm{C}, 1$ min at $55^{\circ} \mathrm{C}$ and $1 \mathrm{~min}$ at $72^{\circ} \mathrm{C}$, followed by a final cycle of $10 \mathrm{~min}$ at $72^{\circ} \mathrm{C}$ for BbA01970, BbF16269 and $\mathrm{BbF} 07573$ primer sets.

Life stages of whiteflies: The identified whiteflies were held on one month old potted sunflower plants (variety RSFH-130) placed in metal insect rearing cages $\left(50 \times 30 \times 50 \mathrm{~cm}^{3}\right)$ covered with plastic mesh $(6 \times 6$ per $\left.\mathrm{cm}^{2}\right)$. The glass panelled front door of the insect rearing cage provided facilities to water the sunflower plant once every two days and to observe the life stages of whiteflies. The life stages were observed on 10 weeks old sunflower plants placed in the cages at the temperature at $28 \pm 2{ }^{\circ} \mathrm{C}$. The observations on the life stages of identified whiteflies were conducted.

Symptoms of infestation: Study was initiated to know the symptoms of whitefly as direct damage and indirect damage to sunflower. For the direct damage, ten pairs of adult whiteflies (non viruliferous) were allowed to feed on 3 weeks old healthy sunflower seedlings. Ten such seedlings were caged in insect proof plastic mesh for a period of 4 weeks of incubation for complete immature and adult colonisation. Foliage of the seedlings was later observed for morphological changes. For the indirect damage, healthy Sunflower plants (10 days old) were inoculated with leaf curl begomovirus (SuLCV) using whiteflies B. tabaci and maintained in insect proof glasshouse for symptoms development. The symptoms exhibited by the experimentally inoculated, sunflower plants were periodically recorded.

\section{RESULTS AND DISCUSSION}

Specific identification: The whitefly species collected from sunflower in the surveyed areas were identified as; Bemisia tabaci (Gennadius) (Hemiptera: Aleyrodidae). The molecular confirmation through PCR test revealed that the none of the test sample of $B$. tabaci could detect the presence of B biotype specific SCAR amplicon. Whitefly samples inoculated on pumpkin big variety failed to produce silver leaf symptoms even after sixty days of inoculation. Hence these studies revealed that the sunflower whitefly was considered as an indigenous type and not a B-biotype.

Life stages of identified whitefly species $B$. tabaci: The results of the study on the pest life cycle under the laboratory conditions showed that B. tabaci passed through four nymphal instars before the adult stage (Table 1). Eggs were whitish to colourless elongated and were laid on mature sunflower leaves, on the underside of the leaf close to mid vein or to lateral veins. Number of eggs in a cluster varied from 2 to 22 . Duration of the egg stage ranged from 5-7 days with a mean of $6.2 \pm 1.4(n=20)$. First instar nymphs were active crawlers with slightly undulated folds on their body. Once the first instars settled on a leaf surface they started feeding (and stopped moving). The first instars nymphs were $0.27-0.31 \mathrm{~mm}$ long and $0.16 \mathrm{~mm}$ wide. Duration of the first instar period ranged from 3 7 days with a mean of $5.6 \pm 1.6(n=20)$. Second instars were sessile, dorso-ventrally flattened and bore spines. The second instars were 0.5-0.6 mm in length and 0.3 in width. Duration of the second nymphal stage was $4.2 \pm 1.5$ days with a range of $4-6$ days $(n=20)$. Third instars were also dorso-ventrally flattened, bearing spines. They were also immobile. Third instars are $0.75-0.8 \mathrm{~mm}$ long and $0.45-0.5 \mathrm{~mm}$ wide. The third instar period lasts for 3-5 days with a mean of $4.4 \pm 1.8$ $(n=20)$. Fourth instar or pupae were easily recognized even with the naked eye due to their whitish, woolly covering over the body. They measured $2-2.2 \mathrm{~mm}$ in length and 0.7-0.75 $\mathrm{mm}$ in width. They were oval and creamy yellow in colour. They took 5-7 days with a mean of $5.6 \pm 1.1$ days to become adults. Adults emerged through a split at one end of the pupal case $(n=20)$.

Adults were weak fliers and were mostly found in the 
Table 1. Duration of different stages of the life cycle of two whitefly species.

\begin{tabular}{lcl}
\hline Growth stages & Mean duration (Days) & Description \\
\hline Egg & $6.2(5-7)$ & Eggs are laid singly or in group in stalked form \\
First instar & $5.6(3-7)$ & $1^{\text {st }}$ instars are crawlers, flat bodied whitish green in color \\
Second instar & $4.2(4-6)$ & white appearance \\
Third instar & $4.4(3-5)$ & white appearance with lightly appearance of eye spots \\
Fourth instar & $5.6(5-7)$ & eye spots become pinkish red body color \\
Adult & & Adult females had a smooth conical shaped abdomen. Females \\
Male & $9.8(7-14)$ & were larger in size compared to males which possessed a tubular \\
Female & $12.6(8-18)$ & shaped abdomen. \\
\hline
\end{tabular}

Table 2. Sequence of different SCAR primers used for the identification of B-biotype of whiteflly.

\begin{tabular}{|c|c|c|c|}
\hline S.N. & & $\begin{array}{c}\text { Size of the SCAR } \\
\text { marker }\end{array}$ & Reference \\
\hline \multirow[t]{2}{*}{1} & BbA01970F GCACCTGCAGATTTCAAAAA & $938 \mathrm{bp}$ & Shankarappa et al., 2007 \\
\hline & BbA01970R CGGGTTTTGGAGGAATAAGT & & \\
\hline \multirow[t]{2}{*}{2} & BbF16269F TCGACGGCTACGTATTTCAT & $239 \mathrm{bp}$ & \\
\hline & BbF16269R GCTCTCATTTTCTGATATCG & & \\
\hline \multirow[t]{2}{*}{3} & BbF07573F ATAGACTGAGATGTTGCCCT & $460 \mathrm{bp}$ & \\
\hline & BbF07573R CTGGATCCTTTAGCACGTTA & & \\
\hline \multirow[t]{2}{*}{4} & BB-1.F ACCCGTTGAATCCTATAGAC & $550 \mathrm{bp}$ & Gupta et al., 2008 \\
\hline & BB-1.R TGTTATGCTTACCCGGAAC & & \\
\hline
\end{tabular}

ventral surface of leaves. However, occasionally they fed on the upper surface of leaves too. Females were larger in size compared to males which possessed a tubular shaped abdomen. Longevity of adult males was 7-14 days with a mean of 9.8 and of the female was 818 days with a mean of 12.6 days. Fecundity under laboratory conditions was $14-26$ with a mean of $19.4 \pm 2.3$ eggs per one female $(n=20)$.

The results of the study revealed the biology of the whitefly species $B$. tabaci on sunflower, which was not reported in India before. However, according to the reports of Wijesekara and Kudagamage (1990) on the life cycle of $B$. tabaci on another host plant guava some variations of the immature stages of the life cycle could be observed compared to the results on sunflower. It was observed that the average number of the eggs (1-18) in a cluster laid by $B$. tabaci on cassava in Sri Lanka was smaller than the average number (80) and however the incubation period of five days at $32^{\circ} \mathrm{C}$ recorded on cotton in America (Fancelli et al., 2008), five days on sweet potato, potato and egg plant (De Barro et al., 2011) in Israel and Egypt, confirmed the results of the presented study. The average developmental period from egg to adult (29.2 days) for B. tabaci was longer than the period recorded for the same species on cotton (23.6 days) by Baldin et al. (2005).

Symptoms of infestation: Whitefly could cause two types of damage i.e. 1) direct damage, 2) indirect damage through virus transmission (Islan and Shunxiang, 2007). In the case of direct feeding, due to piercing and sucking of sap from foliage by immature and adult stages of whiteflies, leading to deposition of honeydew and white, waxy flocculent material over leaf surface. Whereas whiteflies species tested on sunflower, did not induce such symptoms. As vector it is found to transmit the leaf curl begomovirus disease in sunflower. Healthy sunflower seedlings inoculated with viruliferous whiteflies (twenty adults/plant) developed complete symptoms at 4 weeks of inoculation. Symptoms included curling and cupping of leaves which turn leathery due to thickening of veins and vein lets on abaxial surface. Subsequently produced leaves from the infected plants showed yellow discoloration and severe reduction in leaf size. Symptoms were found similar to those of naturally infected plants in the field.

The symptoms of the disease under field condition appear at early stage of the crop i.e. 30 days after sowing as marginal upward curling and cupping of leaves which turn leathery due to thickening of veins and vein lets on abaxial surface. Subsequently produced leaves from the infected plants showed yellow discoloration and severe reduction in leaf size. Thickening of veins and enations were very prominent on abaxial surface of both older and younger leaves. The early infected plants were severely stunted and produced reduced ear head with prominent enations on bracts and capitulum of the ear head. The pest is found to infect the plant in all stages starting from seedling to maturity of the crop. Plants fail to flower if infects early (30 days after sowing) and infected plants remain stunted and will not die or dry as in the case of necrosis. Similar symptoms were observed on tomato infected with ToLCV (Seetharama Reddy, 1978; Saikia and Muniyappa, 1989).

\section{Conclusion}

The SCAR markers were found to be true to their 
identity in finding out the whitefly species related to sunflower as Bemisia tabaci (Gennadius). By using B-biotype specific SCARs Further the identified whitefly species was confirmed to be indigenous $B$. tabaci on molecular basis and biological silver leaf assay on sensitive pumpkin (cv Big variety). None of the whitefly samples could positive for the presence of $\mathrm{B}$ biotype. The results of present study will be useful for disease transmission studies and the future control programmes.

\section{ACKNOWLEDGEMENT}

Authors are thankful to Dr. Sunder Rajan, Institute of Wood Science and Technology, Bangalore, Karnataka for identification of whiteflies.

\section{REFERENCES}

Anonymous. (2009). Sunflower, annul report, 2009-10. All India Coordinated Research Project. Directorate of Oil Seed Research, Rajendranagar, Hyderbad, pp: 225.

Baldin, E. L. L., Vendramim, J. D. and Lourencao, A. L. (2005). Resistance of tomato genotypes to the whitefly Bemisia tabaci (Gennadius) biotype B (Hemiptera: Aleyrodidae). Neotropical Entomology. 34: 435-441.

Boykin, L. M, Shatters, R. G., Rosell, R. C., McKenzie, C. L., Bagnall, R. A., De Barro, P. and Frohlich, D. R. (2007). Global relationships of Bemisia tabaci (Hemiptera: Aleyrodidae) revealed using bayesian analysis of mitochondrial COI DNA sequences. Molecular Phylogenetics and Evolution, 44, 1306-1319.

Brown, J. K. (2000). Molecular markers for the identification and global tracking of whitefly vector-Begomovirus complexes. Virus Res., 71: 233-260.

Chu, D., Zhang, Y. J., Cong, B., Xu, B. Y. and Wu, Q. J. (2005). Identification for Yunnan Q-biotype Bemisia tabaci population. Entomological Knowledge, 42:59-62.

De Barro, P. J., Liu, S. S., Boykin, L. M. and Dinsdale, A. B. (2011). Bemisia tabaci: a statement of species status. Annual Review of Entomology, 56, 1-19.

De Barro, P. J., Driver, F., Trueman, J. W. H. and Curran, J. (2000). Phylogenetic relationships of world populations of Bemisia tabaci (Genn.) using ribosomal ITS1. Molecular Phylogenetics and Evolution, 16, 29-36.

Fancelli, M., Vendramim, J. D. and Lourençao, A. L. (2008). Oviposition and nymphal dispersion of Bemisia tabaci biotype B on tomato genotypes. Bragantia. 67: 933-939.

Govindappa, M. R., Shankergoud, I., Shankarappa, K. S., Wickramaarachchi, W. A. R. T., Anjeneya Reddy, B. and Rangaswamy, K. T. (2011). Molecular detection and partial characterization of begomovirus associated with leaf curl disease of sunflower (Helianthus annuus) in Southren India. Plant Pathol. J., 10 (1): 29-35.

Gupta, V. K., Pawan Sharma, Rakesh Sharma, Jawala Jindal and Dilawari, V.K. (2008). Development of SCAR markers for specific identification of B-biotype of Bemisia tabaci (Gennadius). Ann. Pl. Protec. Sci., 16 (2): 274-281

Gupta, V. K., Dilawari, P., Kumar, A., Sethi and Bons, M. S. (2006). Monitoring of Indian whitefly populations with molecular markers for B-biotype. J. Insect Sci., 19: 57-65.

Islan, M. T. and Shunxiang, R. (2007). Development and reproduction of Bemisia tabaci on three tomato varities. Journal of Entomology, 4: 231-236.

Katti, P. (2007). Sucking pests of sunflower with special reference to Thrips palmi Karny, its relation with necrosis virus and management. Ph.D. Thesis, Univ. Agric. Sci. Dharwad (India). pp:108-112.

Lavanya, N. M., Ramiah, R., Sankaralingam, A., Renukadevi, P. and Velazhahan, R., 2005, Identification of hosts for ilar virus associated with sunflower necrosis disease. Acta Phytopathologica et Entomologica. 40: 31-34.

Perring, T. M. (2001). The Bemisia tabaci species complex. Crop Protection, 20: 725-737.

Saikia, A. K. and Muniyappa, V. (1989). Epidemiology and control of tomato leaf curl virus in southern India. Trop. Agri., 66: 350-354.

Seetharama Reddy, K. (1978). Studies on leaf curl virus disease of tomato. Ph. D., Thesis, Univ. Agri. Sci., Bangalore, India, pp: 134.

Shankarappa, K. S., Rangaswamy, K. T., Aswatha Narayana, D. S., Rekha, A. R., Raghavendra, N., Lakshminarayana Reddy, C. N., Chancellor, T. C. B and Maruthi, M. N. (2007). Development of silver leaf assay, protein and nucleic acid-based diagnostic techniques for the quick and reliable detection and monitoring of biotype $\mathrm{B}$ of the whitefly, Bemisia tabaci (Gennadius). Bulletin of Entomological Research, 97: 503-513.

Wijesekara, G. A. W. and Kudagamage, C. (1990). Life history and control of spiralling whitefly Alerodicus dispersus (Hemiptera: Aleyrodidae): fast spreading pest in Sri Lanka. Quarterly news letter, Asia and Pacific Plant Protection Commission, 33: 22-24. 